\title{
Perancangan Website sebagai Media Penjualan Online IKM di Jawa Timur
}

\author{
Tania Tyaradita Rosandiena dan Baroto Tavip Indrojarwo \\ Departemen Desain Produk, Fakultas Arsitektur, Desain, dan Perancangan, \\ Institut Teknologi Sepuluh Nopember (ITS) \\ e-mail: tavip.baroto@gmail.com
}

\begin{abstract}
Abstrak-Industri kecil menengah atau IKM di Jawa Timur memiliki kontribusi besar dan strategis dalam menopang ketahanan ekonomi dan meningkatkan kesejahteraan masyarakat Jawa Timur, namun masih banyak pelaku IKM yang kurang mempromosikan produknya. Hal ini menyebabkan minimnya pengetahuan dan informasi mengenai IKM terutama di Jawa Timur. Sehingga penjualan produk IKM Jawa Timur kurang maksimal. Perancangan ini dilakukan dengan metode observasi, metode persona, studi literatur dan stuudi eksisting. Tujuan dari perancangan ini adalah merancnag media untuk membantu IKM memasarkan dan mempromosikan produk-produk mereka ke masyarakat luas. Konten dalam website ini adalah informasi mengenai informasi penjualan produk IKM dengan foto-foto produk. Konten tersebut diperlukan sebagai konten pendukung website. Hasil dari perancangan ini adalah media penjualan online produk IKM berupa desain website yang mengusung tema Jawa Timur dengan konsep website business to customer. Fitur customize yang dapat membantu user mendesain produk custom, riwayat pembelian yang dapat membantu user melacak proses pembelian, informasi keunggulan produk, serta berbagai macam produk khas Jawa Timur. Website ini diharapkan mampu meningkatkan minat konsumen membeli produk kerajinan tangan dari pelaku IKM di Jawa Timur.
\end{abstract}

Kata Kunci-IKM, website, onlineshop, kerajinan, Jawa Timur.

\section{PENDAHULUAN}

$\mathrm{I}^{\mathrm{N}}$ NDONESIA sebagai negara berkembang dengan jumlah penduduk terbanyak ke-4 di dunia, memiliki berbagai masalah yang lebih banyak dari negara-negara maju lainnya. Salah satunya adalah masalah kependudukan. Tingginya pertumbuhan penduduk di Indonesia tidak berbanding lurus dengan ketersediaan jumlah lapangan pekerjaan. Ketidakseimbangan ini menimbulkan permasalahan ekonomi di Indonesia. IKM dapat menciptakan kegiatan ekonomi yang kondusif sekaligus membuka lapangan kerja, sehingga dapat menyejahterakan masyarakat. Merujuk pada [1] keberadaan IKM mampu menyerap tenaga kerja sebanyak 9,14 juta orang.

Di Jawa Timur sendiri, IKM memiliki kontribusi besar dan strategis dalam menopang ketahanan ekonomi Jawa Timur. Berdasarkan [2] Jawa Timur merupakan daerah yang memiliki potensi dan daya saing yang kuat dengan produk unggulan terbaik. Selain itu, sumber daya manusia di sana sangat berkualitas. Pemasaran menjadi salah satu penyebab terhambatnya perkembangan IKM, yaitu kemampuan berpromosi IKM yang kerap dinilai masih kurang, baik dalam kegiatannya maupun penyebaran informasi. Hal tersebut menyebabkan pemasaran produk IKM menjadi kurang maksimal.
Dalam kasus ini, media informasi menjadi salah satu sarana yang dibutuhkan untuk mewadahi informasi mengenai IKM. Media informasi tersebut haruslah efektif dan dapat dijangkau masyarakat luas. Di era modern saat ini, internet menjadi sarana informasi yang banyak diminati karena jaringannya yang luas dan aksesnya yang mudah. Informasi tersebut diwadahi dengan situs-situs yang disebut website. Dengan nilai investasi yang kecil, sudah dapat memiliki halaman website di internet yang dapat diakses secara global dari belahan negara manapun.

Berdasarkan [3] jumlah populasi di Indonesia sebanyak lebih dari 7 milyar dan jumlah pengguna internet sebanyak lebih dari 3 milyar, Indonesia sering disebut sebagai pasar potensial digital. Website menjadi media informasi yang efektif bagi pengusaha seperti IKM, karena akses yang mudah dijangkau masyarakat luas. Berdasarkan [4] pelaku IKM akan lebih baik bila diberi wadah online untuk bisa memasarkan produknya. Karena mereka tidak memiliki cukup waktu untuk mempelajari teknologi, mereka lebih fokus untuk produksi Dengan website sebagai media penjualan untuk IKM, masyarakat dapat mendapatkan informasi mengenai produk IKM di Jawa Timur dengan lebih mudah. Perancangan website IKM di Jawa Timur ini mengenai website yang digunakan sebagai media penjualan untuk membantu IKM di Jawa Timur memasarkan produk mereka secara luas.

\section{A. Rumusan Masalah}

Bagaimana merancang website sebagai media penjualan online yang sesuai untuk membantu IKM di Jawa Timur mengenalkan dan memasarkan produk IKM Jawa Timur secara luas?

\section{B. Batasan Masalah}

Batasan masalah dari perancangan ini, antara lain:

1) Peneliti membatasi untuk mengkaji masalah website sebagai media penjualan untuk IKM di Jawa Timur dalam bentuk website

2) Peneliti membatasi untuk mengkaji masalah website secara visual, konten IKM, UI dan UX desain

3) Peneliti membatasi untuk mengkaji konten website dengan informasi usaha, ragam produk dan informasi terkait IKM di Jawa Timur

\section{Tujuan}

Adapun tujuan dari perancangan ini adalah adalah untuk memberikan akses kepada IKM di Jawa Timur berupa website sebagai media penjualan online guna untuk memasarkan usahanya secara luas. 


\section{STUDI ACUAN}

\section{A. Landasan Teori}

\section{1) Perilaku Konsumen}

Merujuk pada [5] Dalam membangkitkan keinginan atas memiliki atau memperoleh produk (interest), perlu untuk mengetahui perilaku konsumen. Dalam perilaku konsumen dikenal Tricomponent Attitude Model, yaitu Cognitive (pengetahuan), Affection (perasaan), dan Conative (kecenderungan perilaku), Selain itu, pengaruh situasi adalah pengaruh yang muncul dari faktor-faktor yang sangat terkait dengan waktu dan tempat, yang tidak tergantung kepada konsumen dan karakteristik objek (produk atau merek).

\section{2) Website}

Website atau disingkat Web merupakan suatu alamat website dalam internet yang akan menampilkan informasi berupa teks, gambar, animasi, suara, maupun video yang hanya dapat diakses apabila memiliki koneksi internet dan diakses melalui browser [6]. Perkembangan teknologi informasi berpengaruh besar terhadap perkembangan di media pada komunikasi pemasaran sehingga media online lebih efektif jika dibandingkan dengan media konvensional seperti media cetak dan elektronik.

\section{3) Elemen pada User Experience}

J. James Garrett (2000) dalam bukunya yang berjudul The Element of User Experience: User-centered design for the $w e b$, Merujuk pada [7] terdapat 5 fase dalam proses menyusun user experience. Fase awal adalah strategy kemudian scope, structure, skeleton dan yang terakhir surface.

\section{4) Desain Web}

Desain web adalah jenis desain grafis yang ditujukan untuk pengembangan dan styling obyek lingkungan informasi internet untuk menyediakan dengan fitur konsumen high-end dan kualitas estetika, hal tersebut merujuk pada [8]. Tujuan desain web adalah untuk membuat situs web atau dokumen elektronik dan aplikasi yang berada pada web server dan menampilkan konten dan fitur antarmuka interaktif kepada pengguna akhir dalam bentuk halaman Web.

\section{5) E-commerce}

E commerce adalah kegiatan jual beli barang atau jasa atau transimisi dana atau data melalui jaringan elektronik berupa internet.

\section{B. Studi Eksisting}

\section{1) Qlapa}

Qlapa adalah situs jual beli online untuk produk handmade dan kerajinan tangan seperti furnitur kayu, perhiasan, hiasan gantung, lukisan, dompet kulit, dan produk buatan tangan lainnya.

\section{2) Craftline}

Craftline.co.id merupakan situs jual beli produk kreatif di Indonesia yang menyediakan tempat khusus para pelaku industri kreatif untuk mengenalkan, mempromosikan, dan menjual seluruh jasa atau produk kreatifnya kepada pasar di seluruh Indonesia bahkan dunia.

\section{3) Otenta}

Otenta adalah situs jual beli online tempat dipertemukannya pencari keunikan kreatifitas Made in Indonesia dengan kreatifitas anak bangsa yang memproduksi karya desain, sandang, perhiasan, aksesori rumah dan dekorasi, produk leather, makanan ringan khas nusantara, hasil alam unggulan seperti kopi dan teh, hingga karya seni seperti lukisan, sketsa, dan kriya.

\section{METODOLOGI PERANCANGAN}

\section{A. Metode Penelitian}

\section{1) Wawancara}

Metode ini bertujuan untuk mengetahui kendala atau permasalahan yang sedang dialami oleh pihak-pihak tertentu. Metode ini dilakukan kepada stakeholder dan beberapa pelaku IKM di Jawa Timur. Dengan adanya wawancara mendalam ini, peneliti dapat mengetahui permasalahan IKM.

\section{2) Observasi}

Metode observasi merupakan metode yang dilakukan dilapangan. Peneliti turun ke lapangan untuk melihat keadaan dan situasi dilapangan. Observasi ini bertujuan untuk mengetahui bagaimana keadaan IKM, apa permasalahan yang dihadapi IKM, siapa yang tertarik dengan IKM dan bagaimana IKM dalam menyampaikan informasi kepada konsumen. Metode observasi ini akan dilakukan di sebuah event yang membuka stan untuk IKM.

\section{3) Customer Journey Map}

Metode ini bertujuan untuk mengetahui secara langsung perilaku user saat mengakses website untuk mencari produk yang diinginkan. Peneliti dapat mengobservasi secara langsung bagaimana perilaku, ketertarikan, kebutuhan, kendala yang dialami user saat mengakses internet. Hasil observasi ini dapat membantu peneliti dalam perancangan ini.

\section{4) Persona}

Pada metode ini, penulis menggali informasi lebih dalam dari target user lebih spesifik yaitu pertimbangan dalam memilih produk, refrensi media yang digunakan, biografi, insight dan kesulitan yang dihadapi user. Tujuannya untuk mengetahui insight mereka ketika berbelanja online dan terhadap produk local.

\section{B. Konsep Desain}

Luaran perancangan dari riset ini adalah sebuah website $e$ commerce yang memasarkan produk IKM Jawa Timur, khususnya produk kriya. Website tersebut diberi brand Krealoka. Website Krealoka merupakan website penjualan tipe business to costumer. Website ini akan ditampilkan pada layar desktop, tablet dan smartphone. Perancangan ini meliputi konsep desain website, dimulai dari riset, wireframe, fotografi serta user experience. Konsep website Krealoka mengacu pada beberapa metode dan sumber, diantaranya studi literatur, observasi dan wawancara untuk menentukan konten website. Studi eksisting dan persona terhadap website sejenis untuk menentukan konsep visual dan user interface. 
Data yang digunakan untuk menyusun konsep perancangan diuraikan dengan mengacu pada salah satu teori pengalaman pengguna (user experience) [7] yang terdiri dari Strategy Plane, Scope Plane, Structure Plane, Skeleton Plane, dan Surface Plane.

\section{PEMBAHASAN DESAIN}

\section{A. 'Strategy}

Target audiens dari perancangan ini adalah wanita atau pria, berusia di atas 25 tahun, sudah bekerja, memiliki penghasilan di atas 3 juta rupiah, pengguna internet, berdomisili di perkotaan, tertarik dengan produk kriya, memiliki karakter yang unik dan menyukai tampil berbeda dan menyukai bepergian

User needs dari perancangan ini adalah mencari produk khas daerah, mencari produk dengan kualitas baik, produk yang sedang populer, deskripsi keunggulan produk, sistem pembayaran yang aman dan terpercaya, ulasan dari konsumen lain, jaminan produk yang berharga tinggi, informasi proses pembelian hingga pengiriman yang update, pemesanan produk custom

\section{B. B) Scope}

Spesifikasi teknis dalam website Krealoka meliputi dimensi layar. Website Krealoka menggunakan fitur responsive website, sehingga terdapat beberapa dimensi yang akan menjadi patokan teknis pembuatan website. Untuk layar desktop menggunakan ukuran maksimal 1920 px, untuk layar smartphone menggunakan layar minimal 320 px.

Konten produk yang dapat ditampilkan pada website Krealoka adalah produk kriya buatan pengusaha Jawa Timur. Pada poin user needs didapatkan bahwa pelaku IKM membutuhkan media untuk memasarkan produknya, audiens membutuhkan informasi penjualan produk IKM, informasi deskripsi produk, lokasi IKM, nama usaha, harga, kategori, rating atau ulasan, foto produk, proses pemesanan, kategori jenis produk, informasi tambahan

\section{Structure}

Struktur informasi disusun berdasarkan hasil studi eksisting. Berikut merupakan diagram yang menggambarkan struktur dan alur informasi website Krealoka

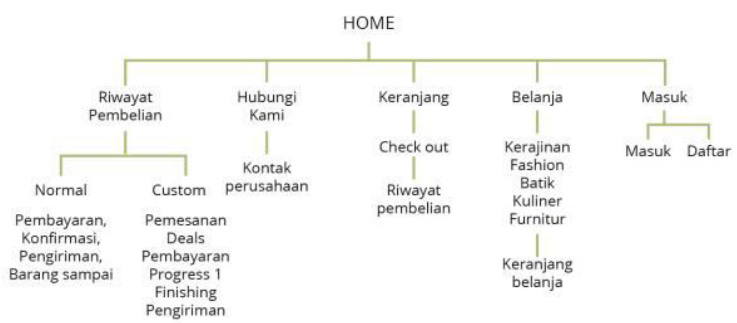

Gambar 1. Site Map.

Sumber: Rosandiena, 2017

\section{Skeleton}

Bagian ini menjelaskan kerangka dari website yang dirancang.

\section{1) 1. Homepage}

Homepage merupakan halaman depan sebuah website. Berisi informasi utama pada website.
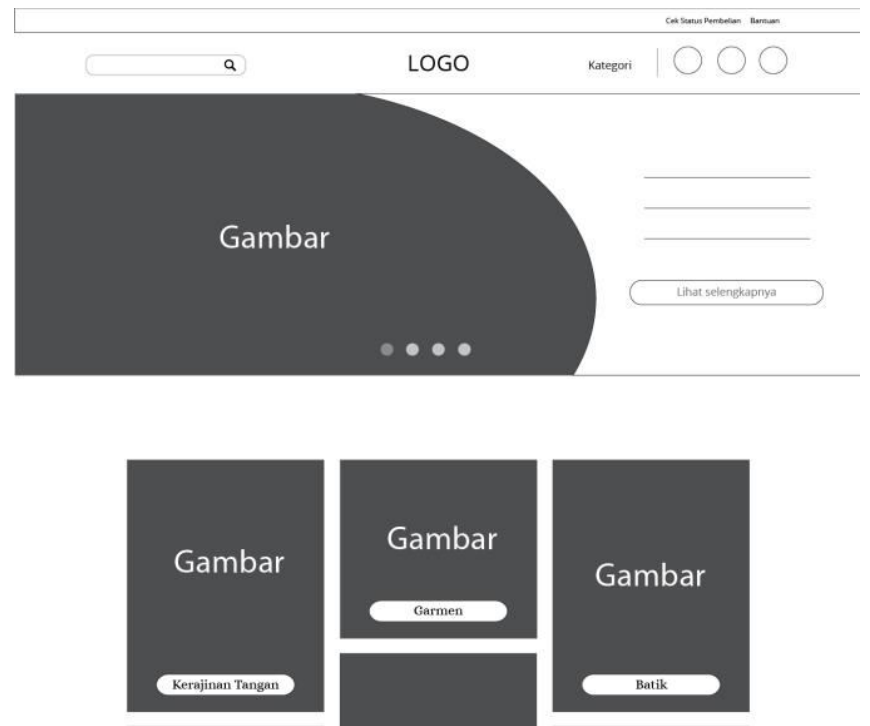

Gambar 2. Sketsa homepage.

2) Shop page

Halaman ini merupakan halaman penjualan produk Krealoka. Berisi informasi produk-produk IKM Jawa Timur.

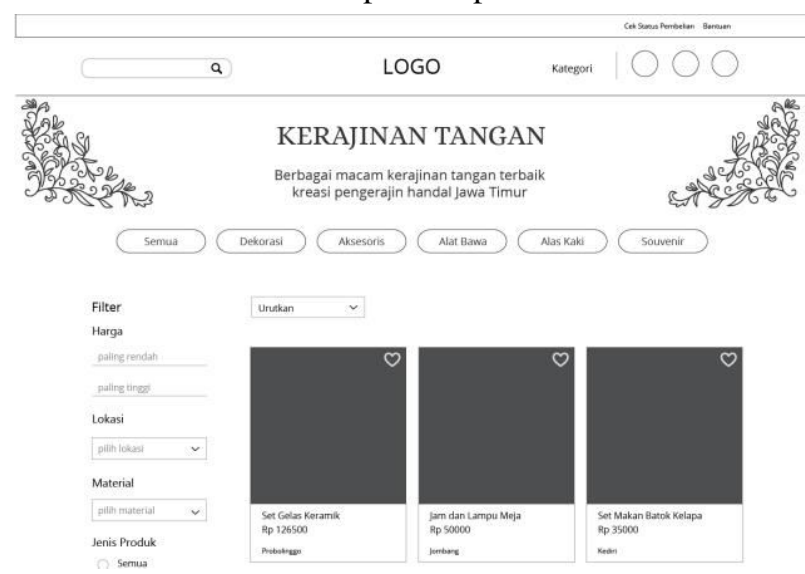

Gambar 3. Halaman belanja.

3) Single product page

Halaman ini adalah halaman preview dari sebuah produk. Halaman ini berisi foto produk secara detail dan deskripsi lengkap dari sebuah produk.

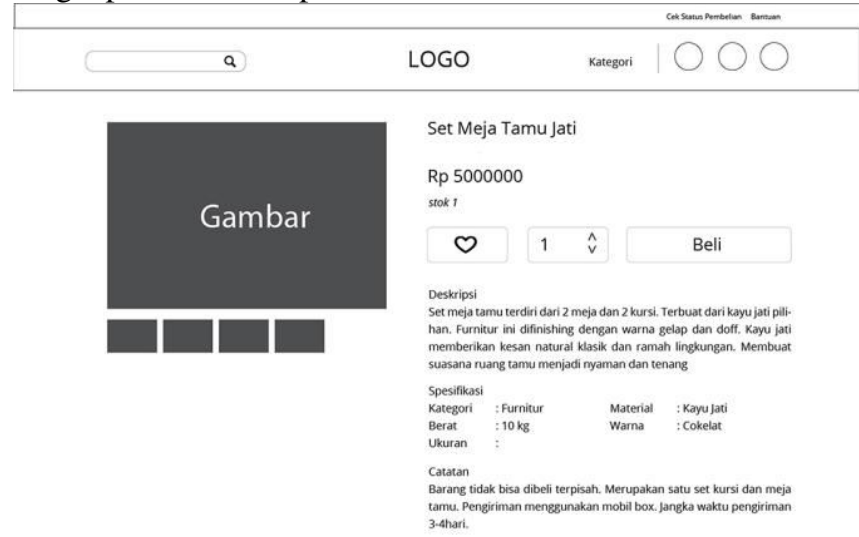

Gambar 4. Halaman deskripsi produk.

4) Cart Page

Halaman ini merupakan halaman keranjang belanja. Disini adalah tempat dikumpulkannya daftar belanja produk yang akan dibeli. 

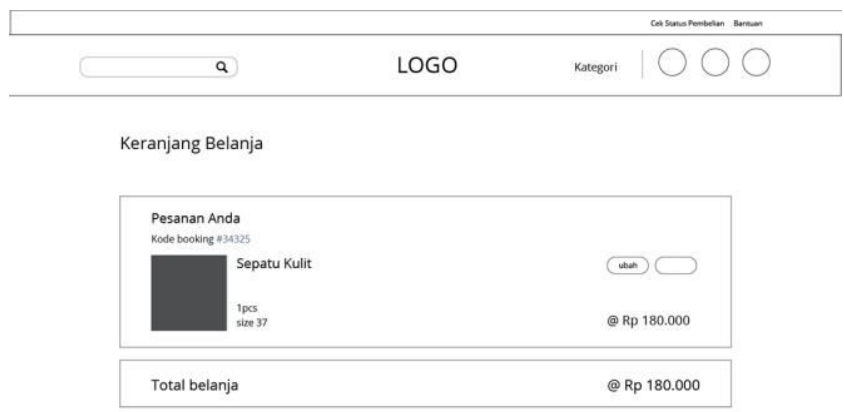

Gambar 5. Halaman keranjang belanja.

5) Cek status pemesanan

Halaman ini merupakan halaman tahapan pembelian produk. Bertujuan untuk mengetahui sampai mana proses pembelian pembeli.

\begin{tabular}{|l|l|l|}
\hline & & \\
\hline LOGO & kategori & $\bigcirc$ \\
\hline
\end{tabular}

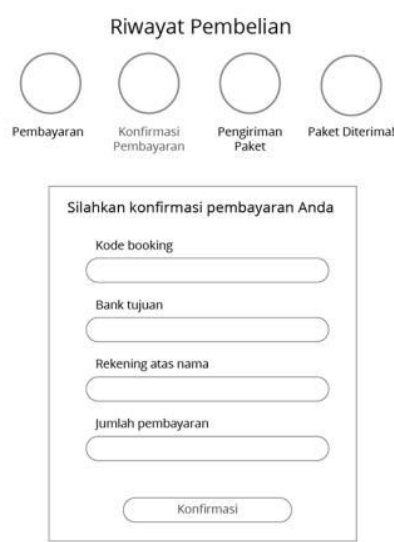

Gambar 6. Halaman riwayat pembelian.

\section{6) Product Customize}

Halaman ini merupakan fitur pemesanan produk customize. User dapat melihat secara langsung produk custom yang dipesan.

\section{E. Surface \\ 1) Warna}

Warna yang digunakan diadaptasi dari penggunaan logo Jawa timur. Yaitu warna biru, kuning dan hijau. Warnawarna tersebut digunakan pada layout, logo, tombol dan elemen desain.

\section{2) $\log o$}

Logo menggunakan elemen logo gram dan logo type. Logo gram menggunakan unsur yang sering digunakan pada motif batik Jawa Timur, yaitu sulur dan dedaunan. Dan logo type menggunakan typeface serif. Sehingga dapat memberikan kesan lokal.

\section{3) Typografi}

Typografi yang digunakan adalah typeface serif dan sans serif. Ddigunakan untuk headline atau judul dan untuk isi. Ukuran typografi paling kecil 14px paling besar 72px.

\section{4) Icon}

Penggunaan icon untuk menggabarkan keterangan tertentu. Gaya icon yang digunakan adalah icon line art. Yang simple dan mudah dipahami. Warna yang digunakan diadaptasi dari konsep warna Krealoka.

\section{KESIMPULAN/RINGKASAN}

Berdasarkan riset yang telah dilakukan dalam proses perancangan website Krealoka, dapat ditarik beberapa kesimpulan sebagai berikut:

Berdasarkan hasil wawancara dengan stakeholder dan ahli e-commerce, penggunaan konsep website e-commerce untuk memasarkan produk IKM Jawa Timur dengan menggunakan konsep bussiness to customer dapat membantu para pelaku IKM memasarkan produk mereka lebih mudah dan lebih luas. Dengan konsep B2C, IKM hanya perlu menyerahkan foto produk yang menarik serta deskripsi yang sesuai, agar dapat dipahami oleh user. Dengan adanya kurasi pada calon penjual, bertujuan agar website lebih terpercaya dari segi kualitas, pembayaran dan proses jual beli dapat dipertanggung jawabkan apabila ada kesalahpahaman. Penggunaan fitur produk custom dan produk eksklusif sebagai fitur pendukung konsep website, membantu user dalam memilih produk kerajinan yang diinginkan. Berdasarkan hasil persona dan user test, konsep proses pemesanan yang terlampir, memudahkan ketiga belah pihak, yaitu pembeli, penjual dan admin, dalam melacak proses pembelian.

\section{DAFTAR PUSTAKA}

[1] Kemenperin, "Daya Saing IKM Perlu Ditingkatkan." [Online]. Available: http://www.kemenperin.go.id/artikel/5210/DayaSaing-IKM-Perlu-Ditingkatkan (9.

[2] B. P. Indra, "Pemerintah Optimalkan Potensi IKM Jawa Timur," Disperindag, 2013. [Online]. Available: http://disperindag.jatimprov.go.id/post/detail?content= pemerintah-optimalkan-potensi-ikm-jawa-timur.

[3] K. SImon, "Digital in 2016," 2016.

[4] Yudhianto, "E-commerce Untuk UKM, Tapi Yang Laku Cuma 5\%," 2016. [Online]. Available: http://inet.detik.com/cyberlife/d3197970/e-commerce-untuk-ukm-tapi-yang-laku-cuma-5.

[5] P. Kotler and K. L. Keller, Manajemen Pemasaran Analisis, Perencanaan, Implementasi dan Pengendalian (terjemahan). Jakarta: Salemba Empat, 1995.

[6] E. Djonov, "Website hierarchy and the interaction between content organization, webpage and navigation design: A systemic functional hypermedia discourse analysis perspective," Inf. Des. J., vol. 15 , no. 2, pp. 144-162, 2007.

[7] J. J. Garrett, "The Element of User Experience: User-centered design for the web," 2000 . 